Revista Eletrônica de Direito Processual - REDP.

Rio de Janeiro. Ano 10. Volume 17. Número 2. Julho a Dezembro de 2016

Periódico Semestral da Pós-Graduação Stricto Sensu em Direito Processual da UERJ

Patrono: José Carlos Barbosa Moreira. ISSN 1982-7636. pp. 57-75

www.redp.uerj.br

\title{
EFICÁCIA DO AGRAVO DE INSTRUMENTO NA DECISÃO ANTECIPADA \\ PARCIAL DE MÉRITO ${ }^{1}$
}

\section{INTERLOCUTORY APPEAL EFFICIENCY IN PARTIAL EARLY MERIT DECISION}

Beclaute Oliveira Silva

Doutor em Direito (UFPE). Mestre em Direito (UFAL). Professor Adjunto de Direito Processual da FDA/UFAL (Mestrado e Graduação). Professor Titular dos Cursos de Direito do CESMAC e da UNIT (Especialização e Graduação). Membro do IIDP. Membro do IBDP (Secretário Adjunto em Alagoas). Membro fundador da ANNEP. Membro da ABDPro (Delegado para o Nordeste), Membro do CEAPRO e da ABDPC. Maceió-AL- Brasil. Vinculado a Faculdade de Direito de Alagoas/UFAL e Curso de Direito do CESMAC e da UNIT.

beclaute@uol.com.br

Ivan Luiz da Silva

Doutor em Direito (UFPE). Mestre em Direito (UFPE). Procurador do Estado de Alagoas. Professor Titular do Curso de Direito do CESMAC. Maceió-AL- Brasil. Vinculado ao Curso de Direito do CESMAC. ivan.luiz@ilsadvocacia.com.br

José Henrique Mouta Araújo

Pós-Doutor pela Faculdade de Direito de Lisboa. Doutor em Direito (UFPA). Mestre em Direito (UFPA). Procurador do Estado do Pará. Professor Titular do Curso de Direito do CESUPA (Mestrado e Graduação) e da Faculdade Metropolitana de Manaus. Membro do IBDP (Secretário Adjunto no Pará). Membro fundador da ANNEP. Membro da ABDPro (Delegado para o Norte). Belém-PA- Brasil. Vinculado ao Curso de Direito do CESUPA. henriquemouta@uol.com.br

\footnotetext{
${ }^{1}$ Artigo recebido em 20/09/2016 e aprovado em 22/11/2016.
} 
Revista Eletrônica de Direito Processual - REDP.

Rio de Janeiro. Ano 10. Volume 17. Número 2. Julho a Dezembro de 2016

Periódico Semestral da Pós-Graduação Stricto Sensu em Direito Processual da UERJ

Patrono: José Carlos Barbosa Moreira. ISSN 1982-7636. pp. 57-75

www.redp.uerj.br

RESUMO: A decisão antecipada parcial de mérito é uma importante técnica de efetivação da prestação jurisdicional disciplinada pelo novo Código de Processo Civil Brasileiro. Com ela é possível decidir parcela do pedido ou de um dos pedidos incontroversos sem que isso implique extinção do processo. Para efetivar a referida decisão, a codificação processual estabeleceu uma sistemática recursal diferenciada, pois, embora se trate de determinação com conteúdo de sentença, pois entrega a prestação jurisdicional, submete-se ao regime de agravo de instrumento, que não possui eficácia suspensiva ope legis, como ocorre, em regra, com a apelação. Com isso, além de a decisão parcial de mérito prestar a jurisdição de forma antecipada, tem sua efetivação provisória facilitada, pois já surge exequível.

PALAVRAS-CHAVE: Processo civil. Sistema recursal. Decisão antecipada parcial de mérito. Eficácia do agravo de instrumento. Eficácia imediata.

ABSTRACT: The partial early decision on merits is an important execution's technique of adjudication which is disciplined by the new Brazilian Civil Procedure Code. Through this technique it is possible to decide portion of the request or one of uncontroversial applications neither incurring in process's extinction. In order to carry out this kind of decision, considering that its determination has sentence's content once it presents adjudication itself, the new Brazilian Civil Procedure Code established a differentiated legal recourse systematic submitted to the interlocutory regime, which has no effective suspension ope legis in comparison with appeal itself. Thus, partial early decision on merits presents beforehand adjudication which turns its provisory effectuation easier, considering its feasible feature.

KEYWORDS: Civil Procedure; Appeal system; Partial early merit decision; Effectiveness of the interlocutory appeal; Immediate effect.

SUMÁRIO: Introdução. 1. Notas sobre a eficácia da decisão judicial. 2. (In)exigibilidade da decisão judicial. 3. Eficácia devolutiva e suspensiva do recurso no CPC/15. 3. Decisão parcial de mérito. 4. Efeito suspensivo ope legis na decisão parcial de mérito. 5. Efeito suspensivo ope judicis na decisão parcial de mérito. 6. Notas conclusivas. Referências. 


\section{Introdução}

A decisão antecipada parcial de mérito, aquela que presta a tutela jurisdicional sem exaurir a totalidade do pedido ou um dos pedidos veiculados no processo, porque parcela do pleito ou um deles ainda depende de julgamento, teve tratamento pormenorizado no art. 356 do CPC/15.

A referida decisão tem conteúdo de sentença, já que sobre ela não cabe novo juízo a ser efetivado pelo mesmo órgão prolator do ato judicial, tanto que fará coisa julgada material caso o recurso não seja interposto ou não haja mais possibilidade de mudança (art. $356, \S 2^{\circ}$, do CPC/15).

O recurso eleito pelo $\mathrm{CPC} / 15$ para rechaçar a referida decisão é o de agravo de instrumento (art. 356, § 5 , do CPC/15). Até aqui não há problema. No entanto, surge uma importante questão: qual a eficácia do agravo de instrumento, no caso de a decisão parcial de mérito corresponder à sentença sujeita a recurso de apelação com efeito suspensivo?

Para analisar a presente questão, primeiro será tratado o tópico eficácia da decisão judicial, já que o efeito suspensivo se dirige a ela.

Após, será estudado o efeito recursal que obsta a eficácia imediata da decisão judicial.

Em seguida, discorrer-se-á sobre a decisão antecipada parcial do mérito e sua importância no CPC/15, para depois se verificar o efeito do recurso no referido ato judicial.

\section{Notas sobre a eficácia da decisão judicial}

A decisão judicial, enquanto fato jurídico, manifesta-se como ato jurídico, pois a vontade ingressa como elemento nuclear do suporte fático ${ }^{2}$, já que o juiz escolhe entre as possibilidades interpretativas qual a que melhor se amolda à solução do caso.

\footnotetext{
${ }^{2}$ PONTES DE MIRANDA, Francisco Cavalcante. Tratado das ações. $2^{\mathrm{a}}$ ed. São Paulo: RT, 1972, t. I, p. 13. Pedro Henrique Nogueira faz excelente análise da decisão judicial sob o prisma da teoria do fato jurídico, apontando aspectos das decisões judiciais como ato-fato jurídico, ato jurídico stricto sensu e negócio jurídico. NOGUEIRA, Pedro Henrique. Negócios jurídicos processuais. Salvador: Juspodivm, 2016, p. 185-222.
} 
Revista Eletrônica de Direito Processual - REDP.

Rio de Janeiro. Ano 10. Volume 17. Número 2. Julho a Dezembro de 2016

Periódico Semestral da Pós-Graduação Stricto Sensu em Direito Processual da UERJ

Patrono: José Carlos Barbosa Moreira. ISSN 1982-7636. pp. 57-75

www.redp.uerj.br

Como fato jurídico, produz efeitos no mundo jurídico. Tais efeitos encontram-se

na relação jurídica que o referido ato jurídico desencadeia. Na relação jurídica, direito corresponde a dever, e pretensão a obrigação. ${ }^{3}$

Os efeitos mínimos da relação jurídica são o direito, que implica necessariamente o dever. ${ }^{4}$ Esses efeitos são categorias relacionais, pois só podem existir se houver o seu oposto. A eliminação de um implica necessariamente a eliminação do outro. Desse modo, quando o sujeito passivo de uma relação jurídica creditícia quita integralmente o seu débito, faz desaparecer o crédito do sujeito ativo e, ato contínuo, de forma lógica e não temporal, elimina a própria relação jurídica e o fato jurídico que a fundamenta.

No entanto, a relação jurídica pode abrigar um direito sem exigibilidade. Trata-se de direito mutilado. ${ }^{5}$ Saliente-se que a exigibilidade se dá na pretensão, que é a "posição subjetiva de poder exigir de outrem alguma prestação positiva ou negativa" ${ }^{6}$. Neste caso, o direito existe, mas por não haver ainda a pretensão, o devedor não está obrigado a cumprilo, embora possa realizá-lo de modo espontâneo.

Uma decisão judicial estabelece um vínculo material, que corresponde, do ponto de vista subjetivo, em regra, à relação jurídica deduzida originariamente em juízo. Diz-se, em regra, pois nada impede que o elemento subjetivo da relação jurídica seja alterado, com acréscimo de terceiros, no curso do processo. Isso pode ocorrer, por exemplo, como consequência da desconsideração da pessoa jurídica (arts. 133 a 137 do CPC/15), como também pode ocorrer, no curso processual, a sucessão de partes por ato inter vivos ou causa mortis (arts. 108 a 110 do CPC/15). De qualquer sorte, o vínculo estipulado na decisão judicial pode nascer exigível ou não.

A inexigibilidade do direito subjetivo no bojo de uma relação jurídica veiculada em decisão judicial pode ser contemporânea ao seu surgimento ou decorrer de fato superveniente. Esse será o objeto do tópico que segue.

\section{2. (In)exibilidade da decisão judicial}

\footnotetext{
${ }^{3}$ PONTES DE MIRANDA, Francisco Cavalcante. Tratado das ações. Op. cit., p. 51.

${ }^{4}$ PONTES DE MIRANDA, Francisco Cavalcante. Tratado das ações. Op. cit., p. 30-31.

${ }^{5}$ PONTES DE MIRANDA, Francisco Cavalcante. Tratado das ações. Op. cit., p. 103.

${ }^{6}$ PONTES DE MIRANDA, Francisco Cavalcante. Tratado das ações. Op. cit., p. 52.
} 
Revista Eletrônica de Direito Processual - REDP.

Rio de Janeiro. Ano 10. Volume 17. Número 2. Julho a Dezembro de 2016

Periódico Semestral da Pós-Graduação Stricto Sensu em Direito Processual da UERJ

Patrono: José Carlos Barbosa Moreira. ISSN 1982-7636. pp. 57-75

www.redp.uerj.br

No contexto da decisão judicial, a inexigibilidade será contemporânea ao

surgimento da relação jurídica quando: a) o direito possuir objeto ilíquido; b) o trânsito em julgado for condição para a sua efetivação; c) a decisão judicial pender de recurso com eficácia legal suspensiva; d) a decisão veicular obrigação subordinada a termo ou a condição. Analisemos cada situação.

No primeiro caso, quando o direito possuir objeto ilíquido, a decisão judicial necessitará ser liquidada, nos termos dos arts. 509-512 do CPC/15, no intuito de determinar os seus contornos. Saliente-se que a liquidação independe do trânsito em julgado da decisão (art. 512 do CPC) e pode ser processada ainda que o recurso seja recebido no efeito suspensivo, isso porque a função da liquidação não é satisfazer o direito do credor, mas de quantificar ou de individuar (quando especifica objeto genérico) uma obrigação veiculada em decisão judicial. ${ }^{7}$

Ademais, o procedimento de liquidação tem por fim integrar ao título a característica liquidez à decisão judicial tornando-o título executivo, pois passa a veicular obrigação certa, exigível e líquida (quantificada ou individualizada). Percebe-se assim que a ausência de liquidez obsta a efetivação do direito impedindo sua exigibilidade.

Mesmo líquida, a exigibilidade pode não ocorrer por conta do efeito suspensivo de eventual recurso ou de necessidade de trânsito em julgado, como ocorre nas obrigações de dar quantia certa contra a Fazenda Pública, por conta da exigência constitucional quanto ao precatório ou à requisição de pequeno valor (art. 100 da $\mathrm{CF} / 88$ ).

Com relação ao efeito suspensivo do recurso, quando é ope legis, deve-se salienta que essa eficácia não decorre da interposição do recurso, mas da própria recorribilidade do ato. Nesse caso, o ato judicial já nasce com sua exigibilidade suspensa ou, como prefere Barbosa Moreira, obstada. Esse obstáculo irá perdurar até o fim do prazo para o recurso ou, caso ele seja interposto, até o seu julgamento. ${ }^{8}$

Há também inexigibilidade quando a decisão veicula situação jurídica subordinada a condição ou a termo. Neste caso, embora não haja impedimento que atinja a

\footnotetext{
7 SILVA, Beclaute Oliveira. In CÂMARA, Helder Moroni (Coordenador). Código de processo civil comentado (art. 521 do CPC/15). São Paulo: Almedina, 2016, p. 673.

${ }^{8}$ MOREIRA, José Carlos Barbosa. Comentários ao código de processo civil. $10^{\mathrm{a}}$ ed., Rio de Janeiro: Forense, 2002, v. 5, p. 257. DIDIER JR, Fredie et al. Curso de direito processual civil. $13^{\mathrm{a}}$ ed. Salvador: Juspodivm, 2016, v. 3, p. 141. JORGE, Flávio Cheim. Teoria geral dos recursos cíveis. São Paulo: RT, 2015 , p. $388-389$.
} 
Revista Eletrônica de Direito Processual - REDP.

Rio de Janeiro. Ano 10. Volume 17. Número 2. Julho a Dezembro de 2016

Periódico Semestral da Pós-Graduação Stricto Sensu em Direito Processual da UERJ

Patrono: José Carlos Barbosa Moreira. ISSN 1982-7636. pp. 57-75

www.redp.uerj.br

decisão, a obrigação que ela veicula só será exigível após o adimplemento da condição ou do termo (art. 514 CPC/15). Trata-se de uma inexigibilidade intrínseca.

Lançou-se até aqui hipóteses em que a decisão ou a obrigação que veicula já nasce inexigível. Passemos a verificar situações em que a decisão nasce eficaz, mas tem sua eficácia suspensa ou obstada.

A decisão judicial pode ser exigível, mas fato superveniente pode tolher esse efeito, por conta de eficácia suspensiva decorrente de decisão posterior veiculada em recurso ou sucedâneo recursal, como a suspensão de segurança ${ }^{9}$ ou a reclamação, por exemplo. Apenas com a remoção dos aludidos obstáculos, a obrigação se torna exigível.

Além disso, a decisão pode ter a eficácia da relação jurídica tolhida por conta do advento da prescrição, ocorrida na fase posterior ao trânsito em julgado da decisão.

Outra hipótese de inexigibilidade superveniente se dá quando a decisão exequenda, antes do trânsito em julgado, toma por base lei ou ato normativo reputado inconstitucional pelo STF no controle difuso ou concentrado. Poderá haver exceção no caso de modulação de efeito (art. 525, §§ 12-14, do CPC/15). Se o trânsito em julgado da referida decisão for anterior à decisão do STF, ela será rescindível (art. 525, § 15, do $\mathrm{CPC} / 15) \cdot{ }^{10}$

Importa para o presente estudo verificar as hipóteses que podem gerar a ineficácia da decisão antecipada parcial de mérito, em face da eficácia obstativa de recurso, ou seja, aquele que impede, no nascedouro, a eficácia da decisão judicial. Para isso falaremos da eficácia devolutiva e suspensiva do recurso, no CPC/15.

\section{Eficácia devolutiva e suspensiva do recurso no $\mathrm{CPC} / 15$}

Preocupado em conferir maior eficácia à decisão judicial, já que é diretriz mestra do $\mathrm{CPC} / 15$, como se percebe da leitura do art. $4^{\circ}$, que enfatiza a duração razoável do processo, incluindo a atividade satisfativa, o sistema recursal passou a ter a devolutividade

\footnotetext{
9 A suspensão de segurança não tem o condão de anular decisão judicial, mas de impedir sua eficácia imediata. Por isso o trânsito em julgado da decisão suspensa por esse sucedâneo recursal faz cessar o efeito suspensivo. (art. 15 da Lei no 12.016/09 - Lei de Mandado de Segurança). Não haverá análise da suspensão de segurança neste texto. Sugere-se para o tema o seguinte trabalho: ARAÚJO, José Henrique Mouta. Mandado de segurança. Salvador: Juspodivm, 2014.

10 SILVA, Beclaute Oliveira. In CÂMARA, Helder Moroni (Coordenador). Código de processo civil comentado (art. 521 do CPC/15). Op. cit., p. 707-708.
} 
Revista Eletrônica de Direito Processual - REDP.

Rio de Janeiro. Ano 10. Volume 17. Número 2. Julho a Dezembro de 2016

Periódico Semestral da Pós-Graduação Stricto Sensu em Direito Processual da UERJ

Patrono: José Carlos Barbosa Moreira. ISSN 1982-7636. pp. 57-75

www.redp.uerj.br

como regra. Essa opção visou dar concreção à garantia constitucional da duração razoável do processo (art. $5^{\circ}$, LXXVIII, da CF/88).

Importante disposição legal corrobora essa assertiva, qual seja a inserta no art. 995, caput, do CPC/15, que se transcreve: “os recursos não impedem a eficácia da decisão, salvo disposição legal ou decisão judicial em sentido diverso". Trata-se de opção do sistema positivo pátrio que procurou implementar a satisfação como efeito relevante da prestação jurisdicional. Mais importante que ter uma decisão é tê-la satisfeita.

O efeito suspensivo conferido às decisões judiciais apeláveis, por exemplo, permanece sendo uma situação excepcional e, por isso, em nome da efetividade, tem exceções com rol ampliado, justamente para que a decisão de mérito possa ser imediatamente efetivada. ${ }^{11}$ Percebe-se isso quando se constata o efeito imediato da sentença que concede, confirma ou revoga tutela provisória, que inclui a cautelar, a antecipada satisfativa e a de evidência (art. 1.012, $\S 1^{\circ}$, do CPC/15). O destaque fica por conta da tutela de evidência, que teve suas hipóteses ampliadas regime atual (art. 311 do $\mathrm{CPC} / 15)$.

Há então duas formas de a decisão, por meio de recurso, ter sua eficácia suspensa, mas ambas são excepcionais. O primeiro caso é o efeito suspensivo ope legis. O segundo caso permitido pelo sistema é a hipótese ope judicis. Analisemos as duas situações de forma sucinta, a seguir.

O primeiro caso - efeito suspensivo ope legis - vislumbramos na hipótese do recurso de apelação (art. 1.012, caput, CPC/15) e do recurso especial ou extraordinário veiculado contra decisão que julga o incidente de resolução de demanda repetitiva - IRDR - (art. 987, §1 $1^{\circ}$, do CPC/15). São regras expressas que estipulam exceções e, como é cediço, interpretam-se exceções de forma restritiva (exceptiones sunt strictissimae interpretationis). ${ }^{12}$

Interessa-nos, no caso, a apelação, pois ela se dirige a decisões de mérito, assim como o agravo de instrumento, em alguns casos. Deve-se deixar claro que é cabível a

\footnotetext{
11 ARAUJO, José Henrique Mouta. “A recorribilidade das interlocutórias no novo CPC: variações sobre o tema. Revista de Processo. São Paulo: RT, vol. 251/2016, p. 207-208, jan/2016. No mesmo sentido, BRUSCHI, Gilberto Gomes; MAIDAME, Márcio Manoel. "O efeito suspensivo e o recurso de apelação - do CPC/1973 ao CPC/2015”. In DIDIER, Jr., Fredie et al. Processos nos tribunais e meios de impugnações às decisões judiciais. Salvador: Juspodivm, 2015, p. 523-538.

${ }^{12}$ MAXIMILIANO, Carlos. Hermenêutica e aplicação do direito. $20^{\mathrm{a}}$ ed. Rio de Janeiro: Forense: 2011, p. 183.
} 
Revista Eletrônica de Direito Processual - REDP.

Rio de Janeiro. Ano 10. Volume 17. Número 2. Julho a Dezembro de 2016

Periódico Semestral da Pós-Graduação Stricto Sensu em Direito Processual da UERJ

Patrono: José Carlos Barbosa Moreira. ISSN 1982-7636. pp. 57-75

www.redp.uerj.br

apelação da sentença, assim definida como aquela que se enquadra na definição legal do art. $203, \S 1^{\circ}$, do CPC $/ 15 .{ }^{13}$

Saliente-se que a eficácia suspensiva da apelação comporta exceção (art. 1.012, § $1^{\circ}$, do CPC). São exceções que visam garantir a efetividade e a satisfação.

Percebe-se que, no caso do efeito suspensivo ope legis, a decisão já nasce inexequível. Esta inexigibilidade é contemporânea ao surgimento da decisão, como já assentado. Assim, em regra, as sentenças, nos moldes do art. 203, § $1^{\circ}$, do CPC/15, surgem com a pecha da inexigibilidade. É importante destacar isso, pois não é a interposição do recurso de apelação que suspende o efeito da sentença, mas ela só terá eficácia plena, em regra, quando transitar em julgado.

Outra hipótese de efeito suspensivo decorre de ato judicial superveniente à decisão exequenda. Trata-se do efeito suspensivo ope judicis. A regra geral para a concessão dessa eficácia está prevista no art. 995, par. ún., CPC/15, que se transcreve: “A eficácia da decisão recorrida poderá ser suspensa por decisão do relator, se da imediata produção de seus efeitos houver risco de dano grave, de difícil ou impossível reparação, e ficar demonstrada a probabilidade de provimento do recurso".

Colhe-se da leitura do dispositivo transcrito que a concessão do efeito suspensivo está condicionada (1) à decisão do relator que reconheça, na efetivação imediata do ato judicial recorrido, risco de dano grave, de difícil ou de impossível reparação, (2) além de ficar demonstrada a probabilidade de provimento do recurso. Perceba-se que são requisitos cumulativos: o risco e a probabilidade de reforma.

A exigência dos dois requisitos pode gerar sérios problemas, já que a probabilidade pressupõe a existência de casos análogos anteriores já decididos.

Pode, entretanto, ocorrer que haja situações novas e também situações que, embora não sejam novas, sofra a força da urgência que reclama um provimento liminar. Aqui há necessidade de o julgador valer-se de argumento que tenha por função tentar superar o que já está estabelecido. São problemas que o relator deverá enfrentar, principalmente quando se trata de situação nova. O dever de argumentar deverá ser forte, pois além de ter o condão de justificar o decidir, terá de persuadir seus pares de sua tese, já

\footnotetext{
13 Art. 203, § 1ํo Ressalvadas as disposições expressas dos procedimentos especiais, sentença é o pronunciamento por meio do qual o juiz, com fundamento, nos arts. 485 e 487, põe fim à fase cognitiva do procedimento comum, bem como extingue a execução.
} 
Revista Eletrônica de Direito Processual - REDP.

Rio de Janeiro. Ano 10. Volume 17. Número 2. Julho a Dezembro de 2016

Periódico Semestral da Pós-Graduação Stricto Sensu em Direito Processual da UERJ

Patrono: José Carlos Barbosa Moreira. ISSN 1982-7636. pp. 57-75

www.redp.uerj.br

que não há parâmetro anterior que justifique a concessão do provimento jurisdicional de caráter suspensivo ou, existindo parâmetro em sentido contrário, a situação exige tratamento diferenciado. $\mathrm{O}$ sistema, para isso, lançou mão das regras previstas nos arts. $8^{\circ} \mathrm{e}$ $489, \S \S 1^{\circ}$ e $2^{\circ}$, ambos do CPC/15.

Advirta-se, no entanto, que o de tais artifícios deve ser sempre excepcional, visando evitar o perecimento do direito, já que o sistema fez escolha, que é o respeito aos dois requisitos anteriormente lançados: probabilidade de reforma e risco.

Com relação ao recurso de agravo de instrumento o sistema determinou que ele poderá ter eficácia suspensiva, porém ope judicis, como se depreende do art. 1.019, I, do CPC/15. ${ }^{14}$ Noutros termos, a decisão que é impugnada via agravo de instrumento terá eficácia imediata, salvo se houver decisão do relator que a suspenda, nos moldes estabelecidos no art. 995, par. ún., do CPC, já citado.

Desta feita, só poderá ser suspensa a decisão se o cumprimento imediato gerar risco e houver probabilidade de reforma da decisão impugnada pelo tribunal, fundamentada analiticamente. Trata-se de regra excepcional.

Antes de adentrar no regime recursal das decisões parciais de mérito, far-se-á uma breve incursão sobre a matéria.

\section{Decisão parcial de mérito}

Em um processo pode-se ter uma única decisão que soluciona a totalidade da lide ou mais de uma decisão - sentenças parciais ou decisão parcial de mérito - cuidando de parcelas do pedido ou de um dos pedidos cumulados. No caso de uma única decisão, há a possibilidade de se ter, materialmente, mais de um julgado (e.g.: cumulação de pedidos, litisconsórcio simples etc.). Nas decisões parciais, o magistrado decide, por exemplo, um dos pedidos, por incontroverso, e após a instrução, decide a parte que restou controvertida. Nas palavras de Cândido Rangel Dinamarco, capítulo de sentença consiste "em toda unidade decisória autônoma contida na parte dispositiva de uma decisão judicial". ${ }^{15}$

\footnotetext{
${ }^{14}$ Art. 1.019. Recebido o agravo de instrumento no tribunal e distribuído imediatamente, se não for o caso de aplicação do art. 932, incisos III e IV, o relator, no prazo de 5 (cinco) dias:

I - poderá atribuir efeito suspensivo ao recurso ou deferir, em antecipação de tutela, total ou parcialmente, a pretensão recursal, comunicando ao juiz sua decisão;

${ }^{15}$ DINAMARCO, Cândido Rangel. Capítulos de sentença. $2^{\mathrm{a}}$ ed. São Paulo: Malheiros, 2006, p. 35.
} 
Revista Eletrônica de Direito Processual - REDP.

Rio de Janeiro. Ano 10. Volume 17. Número 2. Julho a Dezembro de 2016

Periódico Semestral da Pós-Graduação Stricto Sensu em Direito Processual da UERJ

Patrono: José Carlos Barbosa Moreira. ISSN 1982-7636. pp. 57-75

www.redp.uerj.br

Salienta Dinamarco que, por conta dos capítulos de sentença, a decisão pode ser homogênea - quando possui puramente capítulos processuais (veicula decisões sobre a pretensão ao julgamento do mérito) ou quando possui capítulos de mérito (apresenta decisões sobre o próprio mérito) - ou heterogênea - quando o magistrado aprecia questões processuais e as rejeita para só então julgar o mérito. ${ }^{16}$

Uma questão deve ser levada em consideração. Toda decisão que julga o mérito admite, de forma implícita, a viabilidade do seu procedimento. Esta admissão implícita não torna a decisão heterogênea, pois o sistema pátrio não permite validamente decisão implícita, por violar a regra que impõe o dever de fundamentar o provimento judicial. Trata-se aqui da relação forma e conteúdo. A forma é a maneira de manifestação do conteúdo. Admitindo o conteúdo, admite-se a forma, necessariamente. Por tal razão, Fredie Didier Jr. et al. afirmam: "para efeito de aplicação dessa teoria, porém, somente se considera existente um capítulo processual se houver deliberação expressa do juiz sobre a questão de admissibilidade, como ocorre quando o julgador analisa questão processual e a rejeita". ${ }^{17}$

Havendo mais de um capítulo de sentença sobre o mérito, tem-se que cada um poderá transitar em julgado em momentos distintos. Assim, a interposição de recurso parcial - aquele que impugna apenas alguns dos capítulos de sentença - faz com que ocorra preclusão quanto ao capítulo que não restou objetado. Tem-se aqui a denominada coisa julgada progressiva. ${ }^{18}$

No quesito capítulo de sentença, o CPC/15 também inovou ao regular, de forma pormenorizada, o denominado julgamento antecipado parcial do mérito (art. 356 do $\mathrm{CPC}^{19}$ ), que será veiculado por meio de decisão interlocutória de mérito com caráter

\footnotetext{
${ }^{16}$ DINAMARCO, Cândido Rangel. Capítulos de sentença. Op. cit., p. 38-42.

${ }^{17}$ DIDIER JR, Fredie et al. Curso de direito processual civil. 10a ed. Salvador: Juspodivm, 2015, vol. 2, p. 354.

${ }^{18}$ ARAÚJO, José Henrique Mouta. Coisa julgada progressiva. Curitiba: Juruá: Juruá, 2007.

${ }^{19}$ Art. 356. O juiz decidirá parcialmente o mérito quando um ou mais dos pedidos formulados ou parcela deles:

I - mostrar-se incontroverso; II - estiver em condições de imediato julgamento, nos termos do art. 355 . $\S 1^{\circ} \mathrm{A}$ decisão que julgar parcialmente o mérito poderá reconhecer a existência de obrigação líquida ou ilíquida. $\S 2^{\circ}$ A parte poderá liquidar ou executar, desde logo, a obrigação reconhecida na decisão que julgar parcialmente o mérito, independentemente de caução, ainda que haja recurso contra essa interposto. $\S 3^{\circ} \mathrm{Na}$ hipótese do $\S$ $2^{\circ}$, se houver trânsito em julgado da decisão, a execução será definitiva. $\S 4^{\circ}$ A liquidação e o cumprimento da decisão que julgar parcialmente o mérito poderão ser processados em autos suplementares, a requerimento da parte ou a critério do juiz. $§ 5^{\circ}$ A decisão proferida com base neste artigo é impugnável por agravo de instrumento.
} 
Revista Eletrônica de Direito Processual - REDP.

Rio de Janeiro. Ano 10. Volume 17. Número 2. Julho a Dezembro de 2016

Periódico Semestral da Pós-Graduação Stricto Sensu em Direito Processual da UERJ

Patrono: José Carlos Barbosa Moreira. ISSN 1982-7636. pp. 57-75

www.redp.uerj.br

definitivo. Será definitiva, pois analisa um dos pedidos ou parcela dele. ${ }^{20}$ Será interlocutória, pois o procedimento continua sua marcha normal até o julgamento dos demais pleitos ou de parcela deles (art. 356 do CPC/15). Sua demarcação legal foi veiculada no art. $203, \S 2^{\circ}$, do $\mathrm{CPC}^{21}$, pouco importando a natureza da decisão que produz.

Assim, pode ser introduzido no sistema, sob a forma de decisão interlocutória, ato judicial que é, do ponto de vista do conteúdo, sentença - ato judicial em que o magistrado presta a tutela jurisdicional ${ }^{22}$ e confere ao titular do crédito um direito material à prestação - ou decisão processual, como a inversão do ônus da prova, indeferimento de testemunha etc.

A decisão antecipada parcial de mérito, enquanto não transitada em julgado, será provisória, no sentido de que pode ser substituída, em caso de provimento de recurso de agravo de instrumento. Se não for interposto agravo de instrumento, transita em julgado. Faz coisa julgada material.

Como a decisão que julga de forma antecipada parcela de mérito tem caráter definitivo (julga o pedido), com nota de irrevogabilidade pelo juízo a quo, não cabe revisão, reforma ou anulação, salvo para corrigir inexatidão material ou em julgamento de embargos de declaração. Claro, cabe reforma, revisão ou anulação em sede recursal. Interessante notar que não se aplica ao caso o juízo de retratação previsto no art. $1.018, \S 1^{\circ}$, do CPC, já que se trata de decisão com conteúdo definitivo, logo, materialmente sentença. ${ }^{23}$ Analisando o artigo 356 do CPC/15, André Roque foi preciso em sua lição: Em qualquer das hipóteses discutidas no item anterior, consiste o julgamento antecipado parcial em decisão definitiva, conclusiva quanto a uma parcela do mérito, que não pode ser revogada pelo juiz quando for proferir a sentença (art. 494). ${ }^{24}$

${ }^{20}$ DIDIER JR, Fredie et al. Curso de direito processual civil. 13a ed. Salvador: Juspodivm, 2016, v. 3, p. 213-214.

${ }^{21}$ Art. $203, \S 2^{\circ}$ "Decisão interlocutória é todo pronunciamento judicial de natureza decisória que não se enquadre no $\S 1^{\circ}$."

${ }^{22}$ PONTES DE MIRANDA, Francisco Cavalcante. Comentários ao Código de Processo Civil. Rio de Janeiro: Forense, 1974, t. 5.

${ }^{23}$ Nesse sentido, Leonardo Carneiro da Cunha, ao comentar o disposto no antigo art. 475-H, do CPC/73. CUNHA, Leonardo Carneiro da. "Recursos na liquidação de sentença." In NERY JR., Nelson; WAMBIER, Tereza Arruda (Coord.) Aspectos polêmicos e atuais dos recursos cíveis e afins. São Paulo: RT, 2007, v. 11.

${ }^{24}$ ROQUE, André; GAJARDONI, Fernando da Fonseca; OLIVEIRA JR., Zulmar Duarte de; DELLORE, Luiz. Processo de conhecimento e cumprimento de sentença: Comentários ao CPC de 2015. São Paulo: Método, 2016, p. 164. Com a mesma idéia aqui defendida, mas admitindo a retratação apena com relação ao error in procedendo, há o pensamento de Vinicius Silva Lemos. LEMOS, Vinicius Silva. O agravo de instrumento no novo CPC. São Paulo: Lualri Editora, 2016, p. 117-118. 
Revista Eletrônica de Direito Processual - REDP.

Rio de Janeiro. Ano 10. Volume 17. Número 2. Julho a Dezembro de 2016

Periódico Semestral da Pós-Graduação Stricto Sensu em Direito Processual da UERJ

Patrono: José Carlos Barbosa Moreira. ISSN 1982-7636. pp. 57-75

www.redp.uerj.br

Essa ilação cabe para todas as decisões de mérito veiculadas sob a forma de decisão interlocutória de mérito, pois seu caráter definitivo impede que o juiz prolator se valha do juízo de retratação, tal qual ocorre com a sentença.

Noutros termos, a decisão antecipada parcial de mérito presta a tutela jurisdicional - é materialmente sentença -, embora o CPC/15, de forma expressa, a tenha submetida ao sistema de impugnação do agravo de instrumento (art. 356, § $5^{\circ}$, do CPC/15 e também 1.015, II do CPC/15). ${ }^{25}$

Registre-se, ainda, que a decisão parcial de mérito faz coisa julgada material, sendo passível de ação rescisória. Neste sentido, o Enunciado 336 do FPPC: "cabe ação rescisória contra decisão interlocutória de mérito". ${ }^{26}$

Superado esse tópico, passa-se a averiguar a questão da possibilidade do efeito suspensivo ope legis na decisão parcial de mérito

\section{Efeito suspensivo ope legis na decisão antecipada parcial de mérito}

Há decisões parciais de mérito que não terá eficácia imediata. Isso ocorre, por exemplo, no caso da decisão parcial de mérito contra a Fazenda Pública nas obrigações que tenham por objeto dar quantia certa, porque há a necessidade da coisa julgada para fins de expedição do precatório ou da requisição de pequeno valor, por conta da prescrição do art. 100 da CF/88, como já assentado.

Há outra situação que implicará eficácia suspensiva ope legis da decisão parcial de mérito. Trata-se do caso de decisão do STF que considera inconstitucional, sem modular os efeitos, ato normativo que fundamentou a decisão parcial de mérito provisória. Neste caso, por força de lei, a decisão perde sua eficácia. Trata-se de uma perda superveniente de eficácia (art. 525, $\$ 12$ do CPC/15). ${ }^{27}$

Nos demais casos, a decisão parcial de mérito pode ter por objeto pretensão (direito material exigível) que, caso veiculada na forma de sentença, restaria submetida ao

\footnotetext{
${ }^{25}$ Art. 365, § 5 “A decisão proferida com base neste artigo é impugnável por agravo de instrumento". Art. 1015. "Art. 1.015. Cabe agravo de instrumento contra as decisões interlocutórias que versarem sobre: (omissis) II - mérito do processo".

${ }^{26}$ No mesmo sentido, ROQUE, André; GAJARDONI, Fernando da Fonseca; OLIVEIRA JR., Zulmar Duarte de; DELLORE, Luiz. Processo de conhecimento e cumprimento de sentença. Op. cit., p. 168.

27 SILVA, Beclaute Oliveira. In CÂMARA, Helder Moroni (Coordenador). Código de processo civil comentado (art. 525, §12, do CPC/15). São Paulo: Almedina, 2016, p. 700.
} 
Revista Eletrônica de Direito Processual - REDP.

Rio de Janeiro. Ano 10. Volume 17. Número 2. Julho a Dezembro de 2016

Periódico Semestral da Pós-Graduação Stricto Sensu em Direito Processual da UERJ

Patrono: José Carlos Barbosa Moreira. ISSN 1982-7636. pp. 57-75

www.redp.uerj.br

efeito suspensivo da apelação. Neste contexto, poder-se-ia argumentar que o recurso de agravo deveria seguir as restrições impostas à apelação. Ou seja, a decisão não teria eficácia imediata, até que transcorresse in albis o prazo para o agravo ou, sendo este interposto, até seu trânsito em julgado.

Ter-se-ia assim, por analogia, um recurso de agravo com eficácia suspensiva ope legis, já que para a mesma razão, a mesma solução (ubi idem ratio, ibi idem jus). Esse entendimento encontra-se exposto no Enunciado CEAPRO (Centro de Estudos Avançados de Processo) no 13, que estabeleceu: "o efeito suspensivo automático do art. 1.012 aplicase ao agravo de instrumento interposto contra a decisão parcial do mérito."

Apesar de interessante essa posição do CEAPRO, não se adota esta tese neste trabalho, embora se reconheça que o sistema processual está a conferir eficácias distintas a decisões que materialmente possuem o mesmo conteúdo, já que prestam a tutela jurisdicional de forma definitiva, embora ainda sujeita a recurso. ${ }^{28}$

Analisando o tema, Vinícius Silva Lemos entende que não há, para o caso, efeito suspensivo automático. No entanto, defende, para manter a coerência do sistema que o agravante deve requerer no agravo a suspensão com base nas razões para suspensão do recurso de apelação, já que se trata de decisões definitivas. ${ }^{29}$ Essa tese, embora muito sofisticada, não se adota no presente trabalho, pois para resolver o problema, o autor introduz uma nova hipótese, não prevista pelo sistema, para concessão de efeito suspensivo ope judicis.

Como é cediço, o sistema jurídico pode tratar situações análogas de forma diferente, sem que isso implique, necessariamente, inconstitucionalidade, por suposta ofensa a isonomia, por exemplo. Situação interessante se dá com relação à sentença penal condenatória que só é título executivo judicial, no cível, após o trânsito em julgado (art. 515, VI, do CPC). Já a sentença cível que verse sobre o mesmo fato, pode servir como título executivo judicial, ainda que provisório. Outro exemplo é a possibilidade do uso da moratória judicial, no título executivo judicial veiculado no procedimento monitório (art. $701, \S 5^{\circ}$ do $\mathrm{CPC}$ ) e sua vedação no cumprimento de sentença (art. $916, \S 7^{\circ}$ do CPC).

\footnotetext{
${ }^{28}$ Neste sentido, ROQUE, André; GAJARDONI, Fernando da Fonseca; OLIVEIRA JR., Zulmar Duarte de; DELLORE, Luiz. Processo de conhecimento e cumprimento de sentença: Op. cit., p. 167.

${ }^{29}$ LEMOS, Vinicius Silva. O agravo de instrumento no novo CPC. Op. cit., p. 108-109.
} 
Revista Eletrônica de Direito Processual - REDP.

Rio de Janeiro. Ano 10. Volume 17. Número 2. Julho a Dezembro de 2016

Periódico Semestral da Pós-Graduação Stricto Sensu em Direito Processual da UERJ

Patrono: José Carlos Barbosa Moreira. ISSN 1982-7636. pp. 57-75

www.redp.uerj.br

Como se percebe, o ordenamento processual disciplinou de forma diferenciada a decisão antecipada parcial de mérito (art. 356 do CPC), que, do ponto de vista eficacial, tornou-se mais importante que a sentença (art. 203, $\S 1^{\circ}$, do CPC). Foi a opção legislada.

\section{Efeito suspensivo ope judicis na decisão parcial de mérito}

Não há texto sem contexto.

Como estabelecido, o CPC/15 adotou nitidamente a opção pela eficácia imediata da decisão judicial, salvo exceções (art. 995 do CPC/15). Eis o contexto em que se insere o texto. Percebe-se isso, por exemplo, ao se analisar o cumprimento provisório de sentença que autoriza os atos finais de expropriação mesmo sem caução, nos termos do art. 521 do $\mathrm{CPC} / 15$.

Outro ponto que deve ser levado em consideração é a preocupação com que o legislador, de forma pormenorizada, disciplinou a eficácia da decisão antecipada parcial de mérito provisória. Transcreve-se o regramento do art. 356, $\S 2^{\circ}$, do $\mathrm{CPC} / 15$ : “A parte poderá liquidar ou executar, desde logo, a obrigação reconhecida na decisão que julgar parcialmente o mérito, independentemente de caução, ainda que haja recurso contra essa interposto".

Do dispositivo transcrito podem-se perceber algumas estipulações:

a) cabe cumprimento imediato de qualquer decisão parcial de mérito provisória;

b) é uma faculdade do credor; e

c) a dispensa da caução não sofre as limitações previstas no art. 521 do CPC/15, embora ela possa ser exigida no caso do art. 521, par. ún., do $\mathrm{CPC} / 15$, porquanto fundada em urgência. ${ }^{30}$ A restrição aqui é vista apenas com relação a urgência. Registre-se, no entanto, que há vozes divergentes que estende a necessidade de caução quando haja as hipóteses do art. 520, IV do CPC (levantamento de valores). ${ }^{31}$

\footnotetext{
30 SILVA, Beclaute Oliveira. In CÂMARA, Helder Moroni (Coordenador). Código de processo civil comentado (art. 521 do CPC/15). Op. cit., p. 697.

${ }^{31}$ ROQUE, André; GAJARDONI, Fernando da Fonseca; OLIVEIRA JR., Zulmar Duarte de; DELLORE, Luiz. Processo de conhecimento e cumprimento de sentença. Op. cit., p. 166. No mesmo sentido, Enunciado n 49 da ENFAM: "No julgamento antecipado parcial de mérito, o cumprimento provisório da decisão iniciase independentemente de caução (art. 356, § $2^{\circ}$, do CPC/2015), sendo aplicável, todavia, a regra do art. 520, IV".
} 
Revista Eletrônica de Direito Processual - REDP.

Rio de Janeiro. Ano 10. Volume 17. Número 2. Julho a Dezembro de 2016

Periódico Semestral da Pós-Graduação Stricto Sensu em Direito Processual da UERJ

Patrono: José Carlos Barbosa Moreira. ISSN 1982-7636. pp. 57-75

www.redp.uerj.br

Como já afirmado, o recurso cabível da decisão que estipula solução parcial de mérito é impugnável por meio do agravo de instrumento (art. $356, \S 5^{\circ}$, do $\mathrm{CPC} / 15$ ).

O recurso de agravo de instrumento não possui eficácia suspensiva ope legis, mas apenas na hipótese ope judicis. Dessa forma, apenas por decisão, no recurso de agravo de instrumento, pode-se conferir efeito suspensivo apto a impedir a eficácia de decisão parcial de mérito sub judice.

Essa decisão, em sede de agravo, possui natureza predominantemente constitutiva, pois introduzirá, no processo, uma nova situação jurídica. ${ }^{32}$

Outro ponto que deve ser levado em consideração é que a decisão que determina a suspensão deve seguir os requisitos do art. 995, par. ún., do CPC, ou seja, a demonstração da urgência e da probabilidade de sucesso recursal, como já afirmado. Sem esses dois requisitos não se deve suspender o cumprimento da decisão antecipada parcial de mérito provisória. No caso, ela deve seguir seu curso normal até seu termo. Caso haja mudança, por conta do julgamento do agravo de instrumento, por exemplo, o credor responderá objetivamente pelos danos causados ao devedor (art. 520, II, do CPC/15).

Nesse contexto, percebe-se que o agravo de instrumento se insere na regra geral da devolutividade dos recursos. Além disso, regra específica estabelece a eficácia imediata da decisão parcial de mérito provisória, sem estipular a existência de exceção (art. 356, § $2^{\circ}$, do CPC).

Desta feita, onde o legislador não excetuou, não cabe ao aplicador fazê-lo. O legislador deu soluções distintas a soluções análogas, mas isso não fere nenhuma cláusula no ordenamento jurídico constitucional que reclame sua invalidação. No presente caso, pensar diferente, é querer tornar uma exceção, uma regra, sem parâmetro legislado.

Saliente-se que a inexigibilidade do direito veiculado na sentença é consequência da disposição legal que estipula a apelação e não da sentença em si, que veicula relação jurídica que tem sua eficácia obstada, em regra, por determinação legal, até o julgamento da apelação ou até o transcurso do prazo para o recurso, como já assentado.

É a necessidade do julgamento da apelação real (já interposta) ou eventual, que impede a eficácia imediata da sentença, salvo as exceções previstas no art. $1.012, \S 1^{\circ}$, do CPC/15, que inicia seu texto com a seguinte frase: "além de outras hipóteses previstas em

32 JORGE, Flávio Cheim. Teoria geral dos recursos cíveis. $7^{\mathrm{a}}$ ed. São Paulo: RT, 2015, p. 391. 
Revista Eletrônica de Direito Processual - REDP.

Rio de Janeiro. Ano 10. Volume 17. Número 2. Julho a Dezembro de 2016

Periódico Semestral da Pós-Graduação Stricto Sensu em Direito Processual da UERJ

Patrono: José Carlos Barbosa Moreira. ISSN 1982-7636. pp. 57-75

www.redp.uerj.br

lei, começa produzir efeitos imediatamente após a sua publicação a sentença que:...”. Ou

seja, o dispositivo legal transcrito estipula a exceção à suspensividade, prevista no caput do art. 1.012 do CPC (“A apelação terá efeito suspensivo"), em nome da efetividade imediata da decisão, ínsita ao próprio do sistema recursal.

Noutros termos, a eficácia suspensiva ope legis ou está expressa ou não existe. É entender o efeito suspensivo como algo inerente à sentença. Não é. O efeito suspensivo só é intrínseco à decisão no caso de ela veicular obrigações submetidas a termo ou a condições. Nos demais casos, o efeito suspensivo decorre da norma de estrutura ${ }^{33}$ que obsta a eficácia, tanto que há situações em que a sentença produz efeitos imediatos (art. $1.012, \S 1^{\circ}$ do $\left.\mathrm{CPC}\right)$.

Estender para o recurso de agravo de instrumento regra específica da apelação é fazer tábula rasa dos art. 356, § 5º art. 995, caput; art. 1.019, I, todos do CPC, em nome de um sentido material de sentença que o CPC expressamente abandonou, como se percebe do art. 203, § $1^{\circ}$, do CPC/15. É colocar exceção onde o legislador expressamente pôs regra. É desprezar o contexto e negar o texto!

Se houve esquecimento do legislador, não cabe ao intérprete lembrá-lo, salvo se estiver a postular mudança legislativa. Mas aí não se estará a fazer ciência do direito, senão política jurídica ${ }^{34}$, que é importante, porém não serve para o ato de explicar. Essa forma de pensar não pode servir de argumento para, via interpretação, alterar o texto legal, pois isso implicará usurpação da função legislativa. O intérprete, na ciência, não é o legislador. Ele constroi a partir do texto legislado, texto aqui entendido como tudo aquilo que é capaz de comunicar sentido jurídico, os sentidos possíveis.

Por tais razões entende-se que a decisão antecipada parcial mérito provisória, salvo decisão judicial em contrário, ou nas hipóteses expressas em lei, tem eficácia imediata, não se aplicando ao caso as estipulações que suspendem o efeito da sentença em face da apelação.

\footnotetext{
${ }^{33}$ BOBBIO, Noberto. Teoria do Ordenamento Jurídico. Trad. Maria Celeste Cordeiro Leite dos Santos. $1^{\mathrm{a}}$ reimp. Brasília: Polis e Editora Universidade de Brasília, 1990, p. 33-34.

${ }^{34}$ KELSEN, Hans. Teoria pura do direito. Trad. João Baptista Machado. São Paulo: Martins Fontes, 1995, p. 396.
} 
Rio de Janeiro. Ano 10. Volume 17. Número 2. Julho a Dezembro de 2016

Periódico Semestral da Pós-Graduação Stricto Sensu em Direito Processual da UERJ

Patrono: José Carlos Barbosa Moreira. ISSN 1982-7636. pp. 57-75

www.redp.uerj.br

6. Notas conclusivas

A decisão antecipada parcial de mérito tem natureza de sentença, já que presta a tutela jurisdicional de forma definitiva, embora não total, pois o processo continua no intuito de solucionar outros aspectos do objeto litigioso.

Coube ao legislador, de forma expressa, submeter à decisão antecipada parcial de mérito provisória o regime de agravo de instrumento, que não possui eficácia suspensiva ope legis. Deu assim tratamento distinto ao conferido à sentença.

Assim, analisando o contexto do $\mathrm{CPC} / 15$, tem-se tratamento recursal diferenciado para decisão de mérito veiculada sob a forma de sentença e aquela formalizada sob a forma de decisão interlocutória. Na primeira, a regra é a suspensividade; na segunda, apenas a devolutividade.

Embora ambas as decisões possam ter o mesmo conteúdo, por estarem submetidas a regimes recursais distintos, não é razoável a utilização de regras de um recurso sobre o outro, sem expressa previsão legal.

O hibridismo recursal, além de não previsto em lei, macula a regra geral preconizada pelo CPC/15, que é a devolutividade dos recursos. Não seria de bom alvitre ampliar por analogia uma exceção que a lei quer justamente evitar em nome da efetividade e do cumprimento imediato da decisão judicial.

Por essas razões não se adota a tese da eficácia suspensiva ope legis da decisão antecipada parcial de mérito provisória, salvo nas hipóteses de: a) decisão ilíquida; b) decisão contra a Fazenda Pública que tenha por objeto obrigação de dar quantia certa; c) decisão que venha a se tornar ineficaz por conta de o STF, sem modular os efeitos, reputar inconstitucional, no controle difuso ou no concentrado, norma que serviu de base para a decisão parcial de mérito provisória; d) decisão judicial que veicula obrigação submetida a condição ou a termo.

Ademais, a suspensão da eficácia da decisão parcial de mérito provisória deverá seguir as regras do art. 955, par. ún., do CPC/15 (urgência e probabilidade do provimento do recurso). 
Revista Eletrônica de Direito Processual - REDP.

Rio de Janeiro. Ano 10. Volume 17. Número 2. Julho a Dezembro de 2016

Periódico Semestral da Pós-Graduação Stricto Sensu em Direito Processual da UERJ

Patrono: José Carlos Barbosa Moreira. ISSN 1982-7636. pp. 57-75

www.redp.uerj.br

Inaugura assim, o novo CPC, um importante capítulo rumo à efetividade do provimento jurisdicional, já que a decisão parcial de mérito provisória terá, em regra, eficácia imediata.

\section{REFERÊNCIAS BIBLIOGRÁFICAS}

ARAÚJO, José Henrique Mouta. Mandado de segurança. Salvador: Juspodivm, 2014. . Coisa julgada progressiva. Curitiba: Juruá, 2007.

. "A recorribilidade das interlocutórias no novo $\mathrm{CPC}$ : variações sobre o tema.

Revista de Processo. São Paulo: RT, vol. 251/2016, p. 207-208, jan/2016.

BOBBIO, Noberto. Teoria do Ordenamento Jurídico. Trad. Maria Celeste Cordeiro Leite dos Santos. $1^{\text {a }}$ reimp. Brasília: Polis e Editora Universidade de Brasília, 1990.

BRUSCHI, Gilberto Gomes; MAIDAME, Márcio Manoel. "O efeito suspensivo e o recurso de apelação - do CPC/1973 ao CPC/2015”. In DIDIER, Jr., Fredie et al. Processos nos tribunais e meios de impugnações às decisões judiciais. Salvador: Juspodivm, 2015.

CUNHA, Leonardo Carneiro da. "Recursos na liquidação de sentença." In NERY JR.,

Nelson; WAMBIER, Tereza Arruda (Coord.). Aspectos polêmicos e atuais dos recursos cíveis e afins. São Paulo: RT, 2007, v. 11.

DINAMARCO, Cândido Rangel. Capítulos de sentença. 2a ed. São Paulo: Malheiros, 2006.

DIDIER JR, Fredie et al. Curso de direito processual civil. 10ª ed. Salvador: Juspodivm, 2015, vol. 2.

Curso de direito processual civil. 13 a ed. Salvador: Juspodivm, 2016, p. 141.

JORGE, Flávio Cheim. Teoria geral dos recursos cíveis. $7^{\text {a }}$ ed. São Paulo: RT, 2015.

KELSEN, Hans. Teoria pura do direito. Trad. João Baptista Machado. São Paulo: Martins Fontes, 1995.

LEMOS, Vinicius Silva. O agravo de instrumento no novo CPC. São Paulo: Lualri Editora, 2016.

MAXIMILIANO, Carlos. Hermenêutica e aplicação do direito. $20^{\mathrm{a}}$ ed. Rio de Janeiro: Forense: 2011. 
Revista Eletrônica de Direito Processual - REDP.

Rio de Janeiro. Ano 10. Volume 17. Número 2. Julho a Dezembro de 2016

Periódico Semestral da Pós-Graduação Stricto Sensu em Direito Processual da UERJ

Patrono: José Carlos Barbosa Moreira. ISSN 1982-7636. pp. 57-75

www.redp.uerj.br

MOREIRA, José Carlos Barbosa. Comentários ao código de processo civil. 10ª ed., Rio de Janeiro: Forense, 2002, v. 5.

NOGUEIRA, Pedro Henrique. Negócios jurídicos processuais. Salvador: Juspodivm, 2016.

PONTES DE MIRANDA, Francisco Cavalcante. Tratado das ações. $2^{a}$ ed. São Paulo: RT, 1972, t. I.

Comentários ao Código de Processo Civil. Rio de Janeiro: Forense, 1974, t. 5.

ROQUE, André; GAJARDONI, Fernando da Fonseca; OLIVEIRA JR., Zulmar Duarte de;

DELLORE, Luiz. Processo de conhecimento e cumprimento de sentença: Comentários ao CPC de 2015. São Paulo: Método, 2016.

SILVA, Beclaute Oliveira. In CÂMARA, Helder Moroni (Coordenador). Código de processo civil comentado (art. 521 do CPC/15). São Paulo: Almedina, 2016. 